\title{
Risk factor analysis of depression in pediatric acute lymphoblastic leukemia
}

\author{
Mia Ratwita Andarsini ${ }^{1}$, Nining Febriyana ${ }^{2}$, Hilmy Abyan Utama ${ }^{3}$ \\ ${ }^{3}$ Email: hilmy.abyan.utama-2017@fk.unair.ac.id \\ ${ }^{1}$ Department of Pediatrics, Dr. Soetomo Hospital, Universitas Airlangga, Surabaya, Indonesia \\ ${ }^{2}$ Department of Mental Health Sciences, Dr. Soetomo Hospital, Universitas Airlangga Surabaya, Indonesia \\ ${ }^{3}$ Medical Study Program, Faculty of Medicine Universitas Airlangga, Surabaya, Indonesia
}

\begin{abstract}
Objective: This study aims to analyze the risk factors that influence the degree of depression in pediatric ALL patients. Patients with ALL, especially children and adolescents, are faced with many psychological and social problems. One of the most common problems of emotional change is depression. It is still unknown what risk factors can affect the degree of depression in pediatric ALL patients. Methods: A cross-sectional analytical observational study was conductedch by collecting interview data and filling out the PHQ-9 questionnaire from pediatric ALL patients treated at Dr. Soetomo Surabaya in the period September 2020March 2021. The patient's sociodemographic factors, parents' sociodemographic and the patient's clinical condition as a risk factors for the degree of depression were analyzed. The Chi-Square Test, Fischer's Exact Test, and multivariate logistic regression were undertaken. There were 40 samples pediatric ALL patients. Results: Most of the samples (34 patients, 85\%) were grouped in the mild depression group (total PHQ score was 0-9). It was found in the results of the multivariate analysis that had been carried out from several variables analyzed, only comorbidities had $\mathrm{p}=0.007(\mathrm{p}<0.05)$, this showed a significant result. Conclusions: Patient's comorbidities were associated with the severity of depression in pediatric ALL patients
\end{abstract}

Keyword: children's depression; children's ALL; children's ALL depression; relationship between children's ALL depression.

\section{Introduction}

Acute lymphoblastic leukemia (ALL) is the most common type of pediatric cancer with high morbidity associated with the disease itself and the therapy. Patients with ALL, especially children and adolescents, are faced with many psychological and social problems. Children can experience changes in emotionalbehavioral function due to the influence of chemotherapy drugs, painful procedures and frequent visits to the hospital that interfere with activities and their development. This psychosocial disorder does not only occur while the child is undergoing treatment but can persist for a long time even after the patient is declared cured (Kunin-Batson et al., 2016; Mavrides and Pao, 2016).

One of the most common problems with emotional changes is depression. It is estimated that nearly a quarter of patients with ALL suffer from depression. With depression, it will affect medication adherence, 
increase the use of health facilities and drugs, and decrease quality of life. In very severe depression conditions can increase the risk of suicide. Recognition of depressive symptoms and influencing factors must be known by health workers because depression with varying degrees of objection will negatively affect the patient's quality of life and this will affect medical care (Akimana et al., 2019; Khalifa et al., 2014). The purpose of this study was to analyze the risk factors that influence the severity of depression in pediatric ALL patients.

\section{Material and Methods}

\subsection{Population study and setting}

The study was an analytical observational with a cross-sectional design in September 2020-March 2021. Samples were taken from children with a clinical diagnosis of ALL at Dr. Soetomo Hospital Surabaya who met the inclusion and exclusion criteria. Inclusion criteria were children aged 7-18 years, parents signed the informed consent form. Exclusion criteria were patients with incomplete medical record data and hospitalized patients with unstable vital signs (shock, shortness of breath, bleeding, decreased consciousness). The variables studied were age, gender, nutritional status, treatment phase, ALL classification, risk stratification, comorbidities, inpatient care, length of illness, relapse condition, maternal age, and maternal education level, parents' economic status and family history of depression. Enforcement of depression using the Indonesian version of the PHQ-9 screening questionnaire (Levis et al., 2019, Spitzer et al., 1999). The questionnaire is filled out by the patient or asked by the researcher. The results of the measurement of depression in this study were grouped into 2, namely mild depression (0-9) and moderate depression (10-27).

\subsection{Data Analysis}

Bivariate analysis was used to see the relationship between variables using the Chi-Ssquare test analysis or Fisher's Exact test analysis. Bivariate and multivariate logistic regression tests were used to evaluate the role of risk factors on the severity of depression in pediatric ALL patients. The results of the bivariate analysis with $\mathrm{p}$ value $<0.25$ will be continued by the analysis to the multivariate logistic regression test. The results of the study were considered significant if the $\mathrm{p}$ value $<0.05$

\subsection{Research Ethics}

The ethical clearance was approved by the Ethics Committee of Dr. Soetomo Hospital (no 0055/KEPK/IX/2020).

\section{Results}

The total sample was 40 pediatric ALL patients who met the inclusion criteria with 29 inpatients and 11 
subjects from outpatients. Most of the samples (34 patients, 85\%) were grouped in the mild depression group (total PHQ score: 0-9). There are no significant relationship between sociodemographic factors of the sample (age, gender) and the severity of depression in pediatric ALL (Table 1).

Table 1. Bivariate analysis of sample sociodemographic factors with severity of depression

\begin{tabular}{|c|c|c|c|c|c|c|c|c|c|}
\hline \multirow[t]{2}{*}{ Variables } & \multirow[t]{2}{*}{ Classification } & \multicolumn{2}{|c|}{$\begin{array}{c}\text { Moderate-severe } \\
\text { depression }\end{array}$} & \multicolumn{2}{|c|}{ Mild depression } & \multirow[t]{2}{*}{$\mathrm{p}$ value } & \multirow[t]{2}{*}{ OR } & \multicolumn{2}{|c|}{ CI $95 \%$} \\
\hline & & $\mathrm{N}$ & $\%$ & $\mathrm{~N}$ & $\%$ & & & Min & $\operatorname{Max}$ \\
\hline \multirow[t]{2}{*}{ Age } & $7-12$ yo & 5 & 15,6 & 27 & 84,4 & 1,000 & 0,771 & 0,077 & 7,712 \\
\hline & $13-18$ yo & 1 & 12,5 & 7 & 87,5 & & & & \\
\hline \multirow[t]{2}{*}{ Gender } & Male & 5 & 20 & 20 & 80 & 0,381 & 3,5 & 0,368 & 33,308 \\
\hline & Female & 1 & 6,7 & 14 & 93,3 & & & & \\
\hline
\end{tabular}

Table 2 shows the family sociodemographic factors (maternal age, economic status and education level of the mother) does not correlate with the severity of depression. Family history of depression and marital status could not be analyzed because all families were married and had no family history of depression.

Table 2. Bivariate analysis of family sociodemographic factors with severity of depression

\begin{tabular}{|c|c|c|c|c|c|c|c|c|c|}
\hline \multirow[t]{2}{*}{ Variables } & \multirow[t]{2}{*}{ Classification } & \multicolumn{2}{|c|}{$\begin{array}{c}\text { Moderate-severe } \\
\text { depression }\end{array}$} & \multicolumn{2}{|c|}{ Mild depression } & \multirow[t]{2}{*}{$\mathrm{p}$ value } & \multirow[t]{2}{*}{ OR } & \multicolumn{2}{|c|}{ CI $95 \%$} \\
\hline & & $\mathrm{N}$ & $\%$ & $\mathrm{~N}$ & $\%$ & & & Min & Max \\
\hline \multirow[t]{2}{*}{ Maternal age } & $<35$ yo & 4 & 17,4 & 19 & 82,6 & 1,000 & 1,579 & 0,254 & 9,817 \\
\hline & $\geq 35$ yo & 2 & 11,8 & 15 & 88,2 & & & & \\
\hline \multirow{2}{*}{$\begin{array}{l}\text { Economic } \\
\text { status }\end{array}$} & Low & 4 & 18,2 & 18 & 81,8 & 0,673 & 1,778 & 0,286 & 11,039 \\
\hline & High & 2 & 11,1 & 16 & 88,9 & & & & \\
\hline \multirow{2}{*}{$\begin{array}{l}\text { Maternal } \\
\text { education } \\
\text { level }\end{array}$} & Low & 4 & 21,1 & 15 & 78,9 & 0,398 & 2,553 & 0,407 & 15,751 \\
\hline & High & 2 & 9,5 & 19 & 90,5 & & & & \\
\hline \multirow[t]{2}{*}{ Marital status } & Married & 6 & 15 & 34 & 85 & - & - & - & - \\
\hline & $\begin{array}{l}\text { Divorced/not } \\
\text { married }\end{array}$ & 0 & 0 & 0 & 0 & & & & \\
\hline Family & Present & 0 & 0 & 0 & 0 & - & - & - & - \\
\hline $\begin{array}{l}\text { history of } \\
\text { depression }\end{array}$ & None & 6 & 15 & 34 & 85 & & & & \\
\hline
\end{tabular}

The clinical characteristics of the sample in the form of type of treatment, the presence of comorbidities and relapse conditions were significantly related to the severity of depression (Table 3 ). 
Table 3. Bivariate analysis of clinical characteristics of samples with severity of depression

\begin{tabular}{|c|c|c|c|c|c|c|c|c|c|}
\hline \multirow[t]{2}{*}{ Variables } & \multirow[t]{2}{*}{ Classification } & \multicolumn{2}{|c|}{$\begin{array}{l}\text { Moderate-severe } \\
\text { depression }\end{array}$} & \multicolumn{2}{|c|}{ Mild depression } & \multirow[t]{2}{*}{$\mathrm{p}$ value } & \multirow[t]{2}{*}{ OR } & \multicolumn{2}{|c|}{ CI $95 \%$} \\
\hline & & $\mathrm{N}$ & $\%$ & $\mathrm{~N}$ & $\%$ & & & Min & $\operatorname{Max}$ \\
\hline \multirow{2}{*}{$\begin{array}{l}\text { Nutritional } \\
\text { status }\end{array}$} & Malnutrition & 4 & 14,3 & 24 & 85,7 & \multirow[t]{2}{*}{1,000} & \multirow[t]{2}{*}{0,833} & \multirow[t]{2}{*}{0,131} & \multirow[t]{2}{*}{5,403} \\
\hline & Good nutrition & 2 & 16,7 & 10 & 83,8 & & & & \\
\hline \multirow{2}{*}{$\begin{array}{l}\text { ALL } \\
\text { classification }\end{array}$} & ALL 1 & 6 & 16,2 & 31 & 83,8 & \multirow[t]{2}{*}{1,000} & \multirow[t]{2}{*}{1,194} & \multirow[t]{2}{*}{1,036} & \multirow[t]{2}{*}{1,375} \\
\hline & ALL 2 & 0 & 0 & 3 & 100 & & & & \\
\hline \multirow{2}{*}{$\begin{array}{l}\text { Risk } \\
\text { stratification }\end{array}$} & High & 4 & 14,3 & 24 & 85,7 & \multirow[t]{2}{*}{1,000} & \multirow[t]{2}{*}{0,833} & \multirow[t]{2}{*}{0,131} & \multirow[t]{2}{*}{5,304} \\
\hline & Standard & 2 & 16,7 & 10 & 83,3 & & & & \\
\hline \multirow[t]{2}{*}{ Impatient care } & Inpatient & 6 & 20,7 & 23 & 79,3 & \multirow[t]{2}{*}{$0,162^{*}$} & \multirow[t]{2}{*}{0,793} & \multirow[t]{2}{*}{0,659} & \multirow[t]{2}{*}{0,955} \\
\hline & Outpatient & 0 & 0 & 11 & 100 & & & & \\
\hline \multirow[t]{2}{*}{ Comorbidities } & Present & 3 & 75 & 1 & 25 & \multirow[t]{2}{*}{$0,008^{*}$} & \multirow[t]{2}{*}{33} & \multirow[t]{2}{*}{2,568} & \multirow[t]{2}{*}{423,99} \\
\hline & None & 3 & 8,5 & 33 & 91,7 & & & & \\
\hline \multirow{2}{*}{$\begin{array}{l}\text { Length of } \\
\text { illness }\end{array}$} & $\leq 2$ months & 5 & 14,3 & 30 & 85,7 & \multirow[t]{2}{*}{1,000} & 0,667 & 0,061 & 7,254 \\
\hline & $>2$ months & 1 & 20 & 4 & 80 & & & & \\
\hline Relapse & Relapse & 0 & 0 & 12 & 100 & $0,153^{*}$ & 1,273 & 1,049 & 1,544 \\
\hline condition & None & 6 & 21,4 & 22 & 78,6 & & & & \\
\hline Treatment & Induction & 3 & 30 & 7 & 70 & 0,367 & - & - & - \\
\hline phase & Consolidation & 1 & 25 & 3 & 75 & & & & \\
\hline & Maintenance & 2 & 8 & 23 & 92 & & & & \\
\hline & Reintensification & 0 & 0 & 1 & 100 & & & & \\
\hline
\end{tabular}

*significant if $\mathrm{p}<0,25$

The results of logistic regression analysis show the presence of comorbidities is a risk factor that affects the severity of depression in pediatric ALL patients (Table 4)

Table 4. Multivariate analysis of risk factors for depression severity

\begin{tabular}{llll}
\hline Variabel & Adjusted OR & $95 \%$ CI & p value \\
\hline Impatient care & 0,000 & 0,000 & 0,999 \\
Comorbidities & 0,030 & $0,002-0,389$ & $0,007 *$ \\
Relapse condition & 0,000 & 0,000 & 0,999 \\
\hline *significant if $\mathrm{p}<0,05$ & & &
\end{tabular}

\section{Discussion}

Many studies that evaluate depression in pediatric ALL have examined whether depression occurs or not, when depression appears, while those that discuss the severity of it are not discussed in all studies. A review of several studies on depression in children with malignancy showed that most studies found no relationship between age and the occurrence of depression (Margaret and Eric, 2006). Our study is in line with RivasMolina et al., who examined ALL during chemotherapy in the age group 7-16 years, showed that age had no significant correlation with the severity of depression in children with acute leukemia (Rivas-Molina et al, 2015). 
Although males were more likely to have moderate to severe depression, sex in our study was not associated with the severity of depression, in line with the research of Firoozi et al, Myers and Rivas-Molina et al (Firoozi et al, 2011; Myers, 2014; Rivas-Molina et al, 2015). The number of mothers aged 35 years in this study were more likely to experience mild depression but bivariate analysis showed no relationship between maternal age and the degree of depression. Increasing maternal age will improve the quality of life in terms of psychological maturity when facing problems, including readiness when dealing with ill conditions.

Low economic status is at risk for psychosocial disorders due to expensive medical costs and they lose productive time to earn income. As for people with low economic status, health insurance can be done by financing the National Health Insurance. The cost of treatment for ALL is more expensive than the cost of living and transport but covered by National Health Insurance which explains that economic status is not related to depression.

Our research is in line with that of Myers. Myers studied standard-risk pediatric ALL by dividing the education level of mothers who graduated from college and did not. It was found that most of the mother's education did not graduate and the level of mother's education was not associated with the occurrence of depression (Myers, 2014). The higher the level of education will affect a person's mindset so that it is earlier to recognize symptoms of the disease, easier to find information, more anticipatory in dealing with an illness condition. With this mindset, the mother will be able to provide better care for the child so that it will also affect the child's psychology.

Myers research shows that unmarried parents are a significant predictor of worsening depression in children with standard risk ALL (OR=2.36; 95\% CI, 1.17-4.75) (Myers, 2014). Research by Rivas-Molina et al., and Akimana et al. showed that unmarried parents had no significant relationship with the severity of depression in children with malignancy (Akimana, et al, 2019; Rivas-Molina, et al, 2015). Our study subjects all had married parents. If a mother without a husband faces a child with a malignant condition, it will be a tremendous stress for the mother, and the mother's psychological condition will indirectly greatly affect the child's psychological.

Research by Rivas-Molina et al., showed that a family history of depression showed a significant relationship with depression in children with acute leukemia and a significant relationship with the severity of depression (Rivas-Molina, et al, 2015). Research on non-cancer children shows that genetics has a role in depression and anxiety (Nemeroff and Vale, 2005). Research conducted on the survival of ALL with longterm neurocognitive disorders, one of which is depression, shows a genetic role. Variations in the SLCO1B1 and EPHA5 genes are associated with anxiety and depression. The presence of the SLCO1B1 rs4149056 gene which is a gene that affects the steroid and methotrexate pathway shows a significant relationship to the 
occurrence of moderate to severe depression $(\mathrm{p}=0.002)$ (Petrykey et al, 2019). None of our study subjects had a family history of depression, so we could not further analyze the relationship with depression.

Research by Rivas-Molina et al., showed that the type of ALL showed no significant relationship with the occurrence of depression in children with ALL (Rivas-Molina, et al, 2015). Our study was mostly with L1 ALL, while L2 and L3 ALL as many as 3 people all with mild depression. Our study is in line with the RivasMolina study but Rivas-Molina did not differentiate the severity of depression.

A review of several studies showed inconsistent results regarding the association of hospitalization with depression. One study found that children with malignancy admitted to hospital had higher depression scores than those who were outpatient (Margaret \& Eric, 2006). Bivariate analysis showed a significant relationship ( $\mathrm{p}=0.162$ ) between the type of treatment and the severity of depression but after multivariate analysis it was not significantly associated. Treatment in the hospital with the atmosphere, disturbed sleep, procedures that cause pain are conditions that will increase the risk of psychological disorders including depression (Firoozi et al., 2013).

Pediatric ALL is immunocompromised patient's so they are susceptible to have comorbid diseases. Infection remains a major cause of morbidity and mortality in pediatric patients with ALL undergoing chemotherapy (Inaba et al., 2017). Our study subjects who had comorbidities mostly had moderate-to-severe depression. Bivariate and multivariate analysis showed a significant relationship between the presence of comorbidities and the severity of depression. Our study subjects were all with co-morbidities of COVID-19 pneumonia. With these comorbidities, they will require longer hospital stays, treatment in isolation rooms, the child's condition will get worse, chemotherapy can be delayed, the pain will increase so that it will affect the child's psychological condition.

Research on the association between length of illness and depression has yielded vary results. A review that analyzed depression in children with malignancy, with different sample characteristics related to age group, instrument used and type of malignancy found that 12 studies mostly found no relationship between length of illness and depression (Margaret and Eric, 2006). Myers evaluated the difference between duration of illness and the occurrence of depression in children with standard-risk ALL, showing that patients who developed depression at 1 month after diagnosis had a 3.51 greater risk of developing depression 6 months after diagnosis (95\% CI, 1.33-35). 9.26; p=0.015) and 3.31 greater risk for depression 12 months after diagnosis (95\% CI, 1.20-9.10; p=0.023) (Myers, 2014). Our study subjects used a 2-month limit with consideration of the induction phase of about 6 weeks so with 2 months it was assumed that the patient had entered a better adaptation phase. Our study showed no relationship between length of illness and severity of depression. Differences with other studies are related to differences in instruments to determine depression as 
well as the time limit used.

Rivas-Molina et al., showed that the incidence of relapse showed no significant relationship with the occurrence of depression in children with acute leukemia $(\mathrm{p}=0.870)$ nor with the severity of depression $(\mathrm{p}=0.810)$ Rivas-Molina et al, 2015). Our study is in line with that of Rivas-Molina et al although the instruments used are different. With a relapse condition, the child's quality of life will be increasingly disturbed due to the treatment received, disruption of daily activities, and worries about the disease. ${ }^{11}$

Research by Rivas-Molina et al., showed that most of the samples were depressed in the consolidation phase but there was no significant difference in causing depression compared to children who were not depressed (Rivas-Molina et al, 2016). Our study showed that moderate-to-severe depression was more common in children in the induction treatment phase than in other phases, but bivariate analysis showed no significant association. The induction treatment phase, which is the initial phase of therapy, will create a burden for parents and children, related to the patient's medical condition (pain, hospitalization), the initial psychological phase where there will generally be rejection or distrust of the diagnosis, as well as various bodily reactions due to chemotherapy received patient.

\section{CONCLUSION}

The presence of comorbidities is associated with the severity of depression in pediatric ALL patients.

\section{Acknowledgments}

The authors thank the Director of Dr. Soetomo General Hospital, Surabaya Indonesia for supporting this research.

\section{Disclosure of conflict of interest}

"The Authors declare that there is no conflict of interest."

\section{Statement of informed consent}

Informed consent was obtained from all individual participants included in the study.

\section{References}

Akimana, B., Abbo, C., Balagadde-Kambugu, J., \& Nakimuli-Mpungu, E. (2019). Prevalence and factors associated with major depressive disorder in children and adolescents at the Uganda Cancer Institute. BMC Cancer, 19(1), 1-10. https://doi.org/10.1186/s12885-019-5635-z

Baytan, B., Aşut, Ç., Kantarcıoğlu, A. Ç., Evim, M. S., \& Güneş, A. M. (2016). Health-Related Quality of Life, Depression, Anxiety, and Self-Image in Acute Lymphocytic Leukemia Survivors. Turkish Journal of Hematology, 33(4), 326-330. https://doi.org/10.4274/tjh.2015.0356 
Margaret, D., \& Eric, F. (2006). Depression in Paediatric Cancer: An Overview. Psycho-Oncology, 15, 553566. https://doi.org/10.1002/pon.1002

Firoozi, M., Besharat, M. A., \& Pournaghash Tehrani, S. (2011). Cognitive emotion regulation in children with acute lymphoblastic leukemia. Iranian Journal of Cancer Prevention, 4(4), 183-188.

Inaba, H., Pei, D., Wolf, J., Howard, S. C., Hayden, R. T., Go, M., Varechtchouk, O., Hahn, T., Buaboonnam, J., Metzger, M. L., Rubnitz, J. E., Ribeiro, R. C., Sandlund, J. T., Jeha, S., Cheng, C., Evans, W. E., Relling, M. V., \& Pui, C. H. (2017). Infection-related complications during treatment for childhood acute lymphoblastic leukemia. Annals of Oncology, 28(2), 386-392. https://doi.org/10.1093/annonc/mdw557

Khalifa, A. S., Bishry, Z., Tantawy, A. A. G., Ghanem, M. H., Effat, S. M., El Shahawy, H., \& Ebeid, F. S. E. (2014). Psychiatric morbidity in Egyptian children with acute lymphoblastic leukemia and their care providers. Hematology/ Oncology and Stem Cell Therapy, 7(2), 76-84. https://doi.org/10.1016/j.hemonc.2014.01.002

Kunin-Batson, A. S., Lu, X., Balsamo, L., Graber, K., Devidas, M., Hunger, S. P., Carroll, W. L., Winick, N. J., Mattano, L. A., Jr, Maloney, K. W., \& Kadan-Lottick, N. S. (2016). Prevalence and predictors of anxiety and depression after completion of chemotherapy for childhood acute lymphoblastic leukemia: A prospective longitudinal study. Cancer, 122(10), 1608-1617. https://doi.org/10.1002/cncr.29946

Mavrides, N., \& Pao, M. (2014). Updates in Pediatric Psycho-Oncology. International Review of Psychiatry, 26(1), 63-73. https://doi.org/10.3109/09540261.2013.870537.

Myers, R. (2013). A prospective study of anxiety, depression, and behavioral changes in children with acute lymphoblastic leukemia [Yale University School of Medicine]. In Yale Medicine Thesis Digital Library (Issue January). https://elischolar.library.yale.edu/ymtdl/1821

Nemeroff, C. B., \& Vale, W. W. (2005). The neurobiology of depression: inroads to treatment and new drug discovery. The Journal of clinical psychiatry, 66 Suppl 7, 5-13.

Petrykey, K., Lippe, S., Robaey, P., Sultan, S., Laniel, J., Drouin, S., Bertout, L., Beaulieu, P., St-Onge, P., Boulet-Craig, A., Rezgui, A., Yasui, Y., Sapkota, Y., Krull, K. R., Hudson, M. M., Laverdière, C., Sinnett, D., \& Krajinovic, M. (2019). Influence of genetic factors on long-term treatment related neurocognitive complications, and on anxiety and depression in survivors of childhood acute lymphoblastic leukemia: The Petale study. PLoS ONE, 14(6), 1-22. https://doi.org/10.1371/journal.pone.0217314

Rivas-Molina, N. S., Mireles-Pérez, E. O., Soto-Padilla, J. M., González-Reyes, N. A., Barajas-Serrano, T. L., \& Barrera de León, J. C. (2015). Depresión en escolares y adolescentes portadores de leucemia aguda en fase de tratamiento [Depression in school children and adolescents carriers of acute leukemia during the treatment phase]. Gaceta medica de Mexico, 151(2), 174-178. 